\title{
Nodulation and Acetylene Reduction by Cer- tain Rangeland Legume Species under Field Conditions
}

\author{
D.A. JOHNSON AND M.D. RUMBAUGH
}

\section{Abstract}

Acetylene reduction rates, $\mathrm{N}_{2}\left[\mathrm{C}_{2} \mathrm{H}_{2}\right]$, were obtained to estimate nitrogen fixation by several introduced and native range legume species. The $\mathrm{N}_{2}\left[\mathrm{C}_{2} \mathrm{H}_{2}\right]$ fixation rates of excised root segments with attached nodules were measured in the field for legumes from two mountain grassland sites, one native sagebrush-dominated site, and three cultivated former big sagebrush study sites. Sampling was conducted in the driest part of the growing season. Even during this high stress period, nodules were present and active in some legume species. Medicago sativa plants were particularly notable because of their capability of being nodulated and ability to reduce acetylene in dry soils when other legumes were not active. In addition, under the most favorable environmental conditions in this study, nodules from $M$. sativa reduced acetylene most actively at a rate of $26.2 \mu$ moles ethylene $/ \mathrm{h} / \mathrm{g}$ nodule fresh weight. Although nodulation was generally less successful in New World than Old World lupine species, Lupinus mutabilis was capable of reducing acetylene at a rate of $4.97 \mu$ moles ethylene $/ \mathrm{h} / \mathrm{g}$ nodule fresh weight, even in a severely water stressed environment. These results suggested that some legume species may be capable of fixing significant amounts of nitrogen on semiarid range sites.

Plant productivity on western rangelands is frequently limited by lack of nitrogen (N). For example, Wight (1976) estimated that $\mathrm{N}$ deficiency reduces plant production on about 72 million hectares of rangeland in the Northern Great Plains. During a 10-year period of evaluation, $\mathrm{N}$ fertilization increased herbage yields 32 to $114 \%$ for average or near-average precipitation years and $218 \%$ during above-average precipitation years. These yield increases occurred without major species compositional changes in the native vegetation (Wight and Black 1979). $\mathrm{N}$ fertilization of more arid rangelands in the Great Basin increased yields and herbage quality even in a year when soil moisture was exceptionally low (James and Jurinak 1978).

Although forage production on many types of rangelands could be increased by the addition of nitrogenous fertilizers, marginal returns have prohibited fertilizer use on all but a fraction of North American rangelands. This is particularly true of semiarid and arid rangelands where plant response is restricted by low moisture availability throughout most of the growing season. Additional price increases for $\mathbf{N}$ in the future will probably further limit its application to rangelands. Such limitations have increased interest in biological fixation of $\mathbf{N}$ by legume-Rhizobium associations.

Biological $\mathrm{N}$ fixation by legume-Rhizobium associations can increase both the quantity and quality of forage for improved beef gains on pastures (Anthony and Harris 1976; Kaiser and Cmarik 1976). Forage productivity of perennial cool-season grass-legume mixtures in a favorable environment was equivalent to that of the same grass receiving an annual application of 150 to $200 \mathrm{~kg} \mathrm{~N} / \mathrm{ha}$

\footnotetext{
Authors are plant physiologist and research geneticist, USDA-SEA-AR, Crops Research Laboratory, UMC 63, Utah State University, Logan 84322, respectively.

This report is a contribution from the USDA-SEA-AR, in cooperation with the Utah Agricultural Experiment Station, Logan, Utah, Journal Paper No. 2402.

Manuscript received June 6, 1979.
}

(Templeton 1976). Of 19 experiments involving 14 legumes species grown with warm-season grasses in 5 southern states, yearly $\mathrm{N}$ fixation was less than $112 \mathrm{~kg} \mathrm{~N} /$ ha in 12 experiments, somewhat more in 4 tests and over $224 \mathrm{~kg} \mathrm{~N} /$ ha in 3 tests (Burton 1976). An exhaustive economic analysis of pasture date from a subhumid area demonstrated that a zero- $\mathrm{N}$ fertilizer, grass-legume treatment was superior to 112 or $224 \mathrm{~kg} \mathrm{~N} /$ ha fertilizer treatments (Jacobs and Stricker 1976).

Because legumes are known to add significant amounts of $\mathrm{N}$ to subhumid pastures, suggestions have been made to seed or interseed native or introduced legume species on western rangelands. However, plants growing in these arid and semiarid climatic zones of the western U.S. are affected seriously by both drought and high temperature stress. Because of these stresses, it has been proposed that biological $\mathrm{N}$ fixation does not represent a viable alternative for increasing productivity on western rangelands. The effects of high temperature and drought stress on $\mathbf{N}$ fixation processes have recently been examined in Rhizobium associations with crop legumes. However, little is known about the $\mathrm{N}$ fixation capabilities of legume associations growing on the drought and temperature stressed western rangelands (Farnsworth et al. 1978).

This research was conducted to determine whether or not legume-Rhizobium associations growing in semiarid rangeland environments were capable of fixing $\mathbf{N}$ during the most highly stressed portion of the growing season.

\section{Site Descriptions and Methods}

Six study areas were located in northern Utah and southern Idaho. These included two mountain grassland study sites where a large proportion of the precipitation is received as snow. The other sites included one native big sagebrush-dominated site and three cultivated former big sagebrush study sites where the bulk of the precipitation is received during early spring (Table 1). Inoculated seeds were planted at Franklin Basin, Snowville, and Green Canyon in experimental nurseries for range research. The Franklin Basin plots were established during 1957-1968, those at Snowville in 1954, and those at Green Canyon in 1978. Usual practice at the Nephi Dryland Field Station study site was to inoculate all legume seeds, but the available records do not specify that this was done when the test was planted in 1971. Plants used at the Tony Grove and Pocatello Summit locations had invaded or were native to the area. The Tony Grove location is an inactive gravel pit now frequented by deer and elk hunters, campers, and hikers, some of whom use horses. Seeds of Medicago lupulina and Melilotus officinalis are believed to have been brought to the site in hay. The Pocatello Summit is a big sagebrush rangeland with naturally occurring Lupinus spp. Excised root segments with attached nodules were sampled at all sites once during the typically dry mid-summer period, except for the Franklin Basin study site where two samplings were taken.

Acetylene reduction procedures described by Hardy et al. (1973) 
Table 1. Dates legumes were sampled for acetylene reduction and environmental characteristics of study areas.

\begin{tabular}{lcccc}
\hline \hline Location & $\begin{array}{c}\text { Date } \\
\text { sampled }\end{array}$ & $\begin{array}{c}\text { Elevation } \\
(\mathrm{m})\end{array}$ & $\begin{array}{c}\text { Annual } \\
\text { precip. } \\
(\mathrm{cm})\end{array}$ & $\begin{array}{c}\text { Vegetation } \\
\text { type* }\end{array}$ \\
\hline Franklin Basin & $7-11-78$ & & & \\
& $8-11-78$ & 2,600 & 118 & $\mathrm{MG}$ \\
Tony Grove & $7-10-78$ & 2,340 & 127 & $\mathrm{MG}$ \\
Pocatello Summit & $8-16-78$ & 1,500 & 35 & $\mathrm{BS}$ \\
Snowville & $8-16-78$ & 1,417 & 28 & $\mathrm{CS}$ \\
Nephi & $8-23-78$ & 1,615 & 32 & $\mathrm{CS}$ \\
Green Canyon & $7-27-78$ & 1,550 & 41 & $\mathrm{CS}$ \\
\hline
\end{tabular}

* $\mathrm{MG}=$ Mountain grasslands site; $\mathrm{BS}=\mathrm{Big}$ sagebrush-dominated site; $\mathrm{CS}=\mathrm{Cultivated}$ former big sagebrush site.

and modified by Westermann and Kolar (1978) were used to obtain field estimates of nitrogen fixation activity $\left(\mathrm{N}_{2}\left[\mathrm{C}_{2} \mathrm{H}_{2}\right]\right)$. Legume root systems were excavated between noon and 3 p.m. Unwashed root segments with attached nodules were excised from the root system and placed in 20 -cc plastic syringes. Root systems were differentially nodulated both among species and among plants within the same species and resulted in different numbers of nodules available for sampling for each plant. Consequently, some syringe samples consisted of nodules from only one plant, while other samples consisted of nodules from two or more plants. No more than two syringe samples were taken from each excavated root system. Fresh weight nodule mass placed in each syringe averaged 0.0742 grams. Each syringe was filled to $18 \mathrm{cc}$ with ambient air. Then $2 \mathrm{cc}$ of commercial acetylene that had been scrubbed through $\mathrm{H}_{2} \mathrm{SO}_{4}$ and distilled $\mathrm{H}_{2} \mathrm{O}$ traps were drawn into the syringe. This resulted in an atmosphere within the syringe of $10 \%$ acetylene and $90 \%$ air. The samples within the syringe were incubated for 2 hours at ambient temperatures and were shielded from direct sunlight. After the incubation period, gas samples of 11 cc were injected from the syringes in $10 \mathrm{ml}$ stoppered Vacutainers ${ }^{1}$. Although the Vacutainers were new and unused, each Vacutainer was evacuated prior to use for $15 \mathrm{sec}$ with a vacuum pump to insure uniform evacuation. The Vacutainer's stoppers were sealed with paraffin prior to storage.

Ethylene content of the gas samples was determined by use of a gas chromatograph equipped with dual hyd rogen-flame ionization detectors maintained at $150^{\circ} \mathrm{C}$. Prepurified nitrogen was used as the carrier gas and was passed through $1.83 \times 0.003-\mathrm{m}$ stainless steel columns packed with $80-$ to 100 -mesh Poropak N. Column and injection port temperatures were held at 55 and $100^{\circ} \mathrm{C}$, respectively. Gas samples of $100 \mu \mathrm{l}$ were drawn from the Vacutainers and injected into the chromatograph. Retention times for ethylene and acetylene were approximately 30 and 60 seconds, respectively. Ethylene peak heights from duplicate gas samples were used to estimate the amount of ethylene evolved from the nodulated root segments. The scrubbed acetylene contained a small amount of ethylene contaminant that was determined and subtracted from each gas sample. Nodules from sampled root segments were placed in a water-saturated atmosphere for 18 hours before weighing. All $\mathrm{N}_{2}\left[\mathrm{C}_{2} \mathrm{H}_{2}\right]$ activities were expressed as $\mu$ moles of ethylene $/ \mathrm{h} / \mathrm{g}$ of nodule fresh weight.

\section{Results}

Acetylene reduction rates varied considerably among species on the two mountain grassland sites (Franklin Basin and Tony Grove) with Medicago sativa about an order of magnitude above the other legumes (Table 2). The high rate for $M$. sativa was likely due to the favorable soil moisture conditions present on the Franklin Basin site. The nodules from $M$. sativa were not found along the tap root but rather were located in clusters on fibrous roots at a $20-50 \mathrm{~cm}$ depth. Although Lotus corniculatus was actively colonizing adja-

Mention of a trademark name or proprietary product does not constitute endorsement by USDA and does not imply its approval to the exclusion of other products that may also be suitable.
Table 2. Acetylene reduction rates of selected legumes for two mountain grassland study sites, three cultivated former big sagebrush study sites, and one big sagebrush-dominated site in northern Utah. Activity is expressed as $\mu$ moles ethylene/h/g nodule fresh weight.

\begin{tabular}{|c|c|c|c|}
\hline Species & $\begin{array}{l}\text { Native }(\mathrm{N}) \\
\text { or } \\
\text { Introduced }(\mathrm{I})^{\mathrm{t}}\end{array}$ & $\begin{array}{l}\text { Number } \\
\text { of } \\
\text { samples }\end{array}$ & $\begin{array}{l}\text { Activity } \\
\bar{X} \pm s . d .\end{array}$ \\
\hline \multicolumn{4}{|l|}{ Franklin Basin: } \\
\hline Coronilla varia & l & 12 & $0.2 \pm 0.3$ \\
\hline Lotus corniculatus & 1 & 12 & $0.8 \pm 0.6$ \\
\hline Lupinus alpestris & 1 & 7 & $3.1 \pm 5.3$ \\
\hline Medicago sativa & 1 & 7 & $26.2 \pm 5.2$ \\
\hline Trifolium sp. & $\mathbf{N}$ & 12 & $9.2 \pm 6.7$ \\
\hline Vicia cracca & I & 7 & $1.8 \pm 2.1$ \\
\hline \multicolumn{4}{|l|}{ Tony Grove: } \\
\hline Lathyrus leucanthus & $\mathbf{N}$ & 10 & $5.2 \pm 3.8$ \\
\hline Medicago lupulina & I & 10 & $2.2 \pm 2.1$ \\
\hline Melilotus officinalis & I & 10 & $1.5 \pm 0.9$ \\
\hline Lupinus sericeus & $\mathbf{N}$ & - no no & ules found- \\
\hline
\end{tabular}

Nephi

Astragalus cicer
Astragalus falcatus
Hedysarum boreale
Medicago sativa

I $\quad-$ no nodules found --
I $\quad-$ no nodules found - no nodules found $-\longrightarrow$ I Medicago sativa $16 \quad 0.6 \pm 0.4$

Snowville: Medicago sativa $\begin{array}{lll}1 & 3 & 0.3 \pm 0.2\end{array}$ cv. Sevelra

Green Canyon: Medicago sativa cv. Deseret

Onobrychis viciaefolia $\begin{array}{lll}1 & 19 & 1.4 \pm 1.8\end{array}$

Pocatello Valley Summit: Lupinus sp.

'Native or introduced refers to whether or not the species is indigenous to the particular study site.

cent plots not originally seeded with this species, it had one of the lowest acetylene reduction rates at the Franklin Basin site. The second highest acetylene reduction rate at Franklin Basin was in a native Trifolium species growing in a moist streambank area. Plants of Lupinus alpestris, Vicia cracca, and Coronilla varia were all nodulated and reduced acetylene at slower rates than Medicago sativa and the indigenous Trifolium.

At the Tony Grove site Lathyrus leucanthus exhibited the highest acetylene reduction rates (Table 2). However, on a per plant basis Medicago lupulina was the most profusely nodulated species. All plants of Melilotus officinalis bore some active nodules, but none were found on the Lupinus sericeus plants. All excavated Lathyrus leucanthus and Lupinus sericeus plants were on an undisturbed quarry bank, whereas the Medicago lupulina and Melilotus officinalis plants were on a more exposed, xeric, disturbed soilbed where gravel had been excavated. Thus, the higher activity measurements of Lathyrus may have resulted from its more favorable habitat. Because lupines are native to the area, appropriate Rhizobium should have been present in the soil as inoculum. Although the lupine plants did not appear to be under marked moisture deficiency stress at the Tony Grove site, their nodules may have died from drought as reported for other species (Mishustin and Shil'nikova 1971).

Acetylene reduction rates for the legumes from three cultivated former big sagebrush study sites (Nephi, Snowville, and Green Canyon) were considerably lower than those from the higher elevation mountain grasslands (Table 2). Severe plant water deficits, though not specifically measured, were likely present at the time of acetylene reduction sampling on all three cultivated former big sagebrush study sites. For example, during May, June, and July, 1978, a total of $2.5 \mathrm{~cm}$ of precipitation was received at the Nephi Field Station. This record low precipitation resulted in a water 
Table 3. Nodulation and acetylene reduction rates for Lupinus species seeded on a cultivated former hig sagebrush study site at Green Canyon in northern Utah. Activity is expressed as $\mu$ moles ethylene $/ \mathrm{h} / \mathrm{g}$ nodule fresh weight.

\begin{tabular}{lccl}
\hline Species & $\begin{array}{c}\text { Number } \\
\text { of } \\
\text { plants }\end{array}$ & $\begin{array}{c}\text { Plants } \\
\text { with } \\
\text { nodules }\end{array}$ & $\begin{array}{l}\text { Activity } \\
\text { Xs.d. }\end{array}$ \\
\hline New World Lupinus: & & & \\
L. adsurgens & 1 & 0 & - \\
L. albicaulis & 5 & 0 & - \\
L. albifrons & 5 & 0 & - \\
L. bicolor & 1 & 0 & - \\
L. burckii & 1 & 0 & - \\
L. concinnus & 2 & 0 & - \\
L. cruckshankii & 3 & 0 & - \\
L. erectus & 1 & 0 & - \\
L. hartwegii & 3 & 1 & $0.00 \pm 0.00$ \\
L. hirsutas & 4 & 3 & $0.03 \pm 0.10$ \\
L. hirsutissinus & 1 & 0 & - \\
L. leucophyllus & 0 & 0 & - \\
L. luteolus & 4 & 0 & - \\
L. mutabilis & 12 & 8 & $4.97 \pm 1.26$ \\
L. pachylobus & 1 & 1 & $0.01 \pm 0.00$ \\
L. rothmaleri & 1 & 0 & - \\
L. sericeus & 2 & 0 & - \\
Old World Lupinus: & & & \\
L. albus & 87 & 32 & $0.01 \pm 0.03$ \\
L. angustifolius & 16 & 5 & $0.09 \pm 0.28$ \\
L. luteus & 9 & 0 & - \\
\hline
\end{tabular}

content in the upper $91 \mathrm{~cm}$ of soil of only $6.4 \%$ for the late August sampling date on this site. Even with this severe water stress, Medicago sativa still exhibited acetylene reduction capability. No nodules were found on roots of the other three legume species seeded at Nephi. Although Hedysarum boreale is not native to the particular site, this legume is native to surrounding areas within 15 miles of Nephi. Several species of Astragalus also are indigenous in the vicinity of the study site, but the two seeded taxa are introduced. Consequently, the Rhizobium present in the soil might not have been capable of infecting some of the legumes on the Nephi site.

Nodules from Medicago sativa plants at Snowville were more active than those from lupines growing on a big sagebrushdominated site at the Pocatello Valley Summit (Table 2). Medicago sativa nodules from Green Canyon also were much more active than those of Onobrychis viciaefolia growing in the same nursery.

A number of Lupinus species were assayed for acetylene reduction rates at the cultivated former big sagebrush study site at Green Canyon (Table 3). These seeded species included 17 species of New World lupines from either North or South America and 3 species of Old World lupines from the Mediterranean region of southern Europe and northern Africa. Although seeds of these species were treated with commercial peat-base inoculum, 13 species of New World lupines exhibited no nodulation. Conversely only 1 of the 3 Old World lupines was not nodulated. Of the 6 Lupinus species that were nodulated, only $L$. mutabilis exhibited considerable acetylene reduction rates.

\section{Discussion}

High temperature could have contributed to some of the low acetylene reduction rates found in this study. Temperatures between 20 and $35^{\circ} \mathrm{C}$ produced maximum $\mathrm{N}$ fixation rates for most temperature legumes (Gibson 1971). Environmental rhizosphere limitations of soybean (Glycine max) $\mathrm{N}$ fixation included low and high rhizosphere temperatures, slow response to heating and low reversibility (Hardy and Criswell 1976). Over the range of 14 to $34^{\circ} \mathrm{C}$ the equilibrium response of soybean $\mathrm{N}_{2}\left[\mathrm{C}_{2} \mathrm{H}_{2}\right]$ fixation to altered temperature was quadratic, with optima at 22 to $24^{\circ} \mathrm{C}$ and greater decreases caused by heating than by cooling.
Drought stress also probably contributed to the low acetylene reduction rates obtained in this study. Drought stress has been shown to seriously reduce $\mathrm{N}$ fixation in a number of legumeRhizobium associations (Sprent 1971a and b, 1972, 1976; Engin and Sprent 1973; Minchin and Pate 1975; Pankhurst and Sprent 1975; Foulds 1978). Soil moisture stress had particularly deleterious effects on shallow-rooted legumes (Ward et al. 1966). Extremes of soil moisture also adversely affected root nodule bacteria (Engin and Sprent 1973; Sprent 1971a; Vincent 1965). Iotus corniculatus plants grown from seeds placed in soil of low average moisture content had small, white, and nonfunctional nodules with up to $55 \%$ of the plants still not nodulated 77 days after seeding (McKee 1961). Two or more weeks of desiccation of inoculated seeds of Medicago sativa and Lotus corniculatus in a dry seed bed reduced inoculation and produced $\mathrm{N}$ deficiency in the legumes (Alexander and Chamblee 1965). Pate (1976) summarized the effects of drought stress on symbiotic $\mathrm{N}$ fixation; however, most of the conclusions were based on data collected from legumes that evolved in mesic environments.

Mishustin and Shil'nikova (1971) stated that optimum soil moisture for inoculation was 60 to $70 \%$. They observed a death of formed nodules with lack of moisture although plant species are known to differ in their critical moisture thresholds (Kornilov and Verteletskaya 1952). Onobrychis viciaefolia formed nodules well when the soil was only slightly wet, while Medicago sativa was very sensitive to a lack of moisture. However, in the present study Medicago sativa was nodulated in semiarid environments when other legumes were not and exhibited higher $\mathrm{N}_{2}\left[\mathrm{C}_{2} \mathrm{H}_{2}\right]$ rates than other legumes grown in the same environments (Table 2). This difference may be attributed to cultivar and/or Rhizobium differences.

The acetylene reduction rates reported in this study represent measurements taken during only one portion of the growing season. As such, these values may not reflect acetylene reduction capabilities of plants sampled during other portions of the growing season or growing in more favorable environments. It is important to note that nodulation was present and nodules were active even during the most highly stressed portion of the semiarid growing season. This suggests that rates of biological nitrogen fixation by legume-Rhizobium associations might be considerable in April, May, or June when temperature and moistu re availability are more favorable.

Field assessments of nitrogen fixation capabilities throughout the entire Intermountain West growing season and controlled laboratory studies examining the effects of drought and temperature stress on range legume nitrogen fixation are needed. Research dealing specifically with legume-Rhizobium species growing in semiarid range environments is needed because of possible adaptations that may enable these species to function better under marked drought and high temperature stress. Research in these areas is currently underway in our laboratory.

\section{Literature Cited}

Alexander, C.W., and D.S. Chamblee. 1965. Effect of sunlight and drying on the inoculation of legumes with Rhizobium species. Agron. J. 57:550553

Anthony, W.B., and R.R. Harris. 1976. Effects of legumes on performance of grazing animals. In: Biological N Fixation in Forage-Livestock Systems. ASA Spec. Pub. No. 28. p. 73-84. Madison, Wis.

Burton, G.W. 1976. Legume nitrogen versus fertilizer nitrogen for warmseason grasses. In: Biological N Fixation in Forage-Livestock Systems. ASA Spec. Pub. No. 28. p. 55-72. Madison, Wis.

Engin, M., and J.I. Sprent. 1973. Effects of water stress on growth and nitrogen fixing activity of Trifolium repens. New Phytol. 72:117-126.

Farnsworth, R.B., E.M. Romney, and A. Wallace. 1978. Nitrogen fixation by microfloral-higher plant associations in arid to semiarid environments. In: Nitrogen in Desert Ecosystems. N.E. West and J.J. Skujins (Eds.). Dowden, Hutchinson, and Ross, Inc. Stroudsburg, Pa. p. 17-19.

Foulds, W. 1978. Response to soil moisture supply in three leguminous species. II. Rate of $\mathrm{N}_{2}\left[\mathrm{C}_{2} \mathrm{H}_{2}\right]$-fixation. New Phytol. 80:547-555. 
Gibson, A.H. 1971. Factors in the physical and biological environment affecting nodulation and nitrogen fixation by legumes, Plant Soil Spec. Vol. p. 139-152.

Hardy, R.W.F., R.C. Burns, and R.D. Holsten. 1973. Applications of the acetylene-ethylene assay for measurement of nitrogen fixation. Soil Biol. Biochem. 5:47-81.

Hardy, R.W.F., and J.G. Criswell. 1976. Assessment of environmental limitations of symbiotic $\mathrm{N}_{2}\left[\mathrm{C}_{2} \mathrm{H}_{2}\right]$ fixation: temperature and $\mathrm{p}_{2}$. Agron. Abstr. p. 72.

Jacobs, V.E., and J.A. Stricker. 1976. Economic comparisons of legume nitrogen and fertilizer nitrogen in pastures. In: Biological N Fixation in Forage-Livestock Systems. ASA Spec. Pub. No. 28. p. 109-127. Madison, Wis.

James, D.W., and J.J. Jurinak. 1978. Nitrogen fertilization of dominant plants in the northeastern Great Basin Desert. In: Nitrogen in Desert Ecosystems. N.E. West and J.J. Skujins (Eds.). Dowden, Hutchinson, and Ross, Inc. Stroudsburg, Pa. p. 219-231.

Kaiser, C.J., and G.F. Cmarik. 1976. Finishing slaughter cattle on pasture. In: Biological N Fixation in Forage-Livestock Systems. ASA Spec. Pub. No. 28. p. 85-107. Madison, Wis.

Kornilov, A.A., and V. Verteletskaya. 1952. Penetration of sainfoin into dry steppe regions and the role of nodule bacteria. Microbiologiya 20:423-428.

McKee, G.W. 1961. Some effects of liming, fertilization, and soil moisture on seedling growth and nodulation in birdsfoot trefoil. Agron. J. 53:237240.

Minchin, F.R., and J.S. Pate. 1975. Effects of water, aeration, and salt regime on nitrogen fixation in a nodulated legume-definition of an optimum root environment. J. Exp. Bot. 26:60-69.

Mishustin, E.N., and V.K. Shil'nikova. 1971. Biological fixation of atmospheric nitrogen. Penn. State Univ. Press. Univ. Park, Pa.
Pate, J.S. 1976. Physiology of the reaction of nodulated legumes to environment. In: Symbiotic Nitrogen Fixation in Plants. P.S. Nutman (Ed.). Cambridge Univ. Press. N.Y. p. 335-360.

Pankhurst, C.E., and J.I. Sprent. 1975. Effects of water stress on respiratory and nitrogen-fixing activity of soybean root nodules. J. Exp. Bot. 26:287-304.

Sprent, J.I. 1971a. Effects of water stress on nitrogen fixation in root nodules. Plant Soil Spec. Vol. p. 225-228.

Sprent, J.I. 1971b. The effects of water stress on nitrogen-fixing root nodules. I. Effects on the physiology of detached soybean nodules. New Phytol. 70:9-17.

Sprent, J.I. 1972. The effects of water stress on nitrogen-fixing root nodules. IV. Effects on whole plants of Vicia faba and Glycine max. New Phytol. 71:603-611.

Sprent, J.I. 1976. Water deficits and nitrogen-fixing root ndules. In: Water Deficits and Plant Growth. Vol. 4. T.T. Kozlowski (Ed.). Academic Press. N.Y. p. 291-315.

Templeton, W.C., Jr. 1976. Legume nitrogen versus fertilizer nitrogen for cool-season grasses. In: Biological N Fixation in Forage-Livestock Systems. ASA Spec. Publ. No. 28. p. 35-54. Madison, Wis.

Vincent, J.M. 1965. Environmental factors in the fixation of nitrogen by the legume. In: Soil Nitrogen. W.V. Bartholemew and F.E. Clark (Eds.). Amer. Soc. Agron. Madison, Wis. p. 384-435.

Ward, C.Y., J.N. Jones, J.H. Lillard, J.E. Moody, R.H. Brown, and R.E. Bluser. 1966. Effects of irrigation and cutting manament on yield and hotanical composition of selected legume-grass mixtures. Agron. J. 58:181-184.

Westermann, D.T., and J.J. Kolar. 1978. Symbiotic $\mathrm{N}_{2}\left[\mathrm{C}_{2} \mathrm{H}_{2}\right]$ fixation by bean. Crop Sci. 18:986-990.

Wight, J.R. 1976. Range fertilization in the northern great plains. J. Range Manage. 29:180-185.

Wight, J.R., and A.L. Black. 1979. Range fertilization: Plant response and water use. J. Range Manage. 32:345-349. 